\title{
Plastic Bronchitis in a 4 Year-Old Boy Presenting with a Foreign Body Aspiration: A Rare Entity
}

\author{
Yabancı Cisim Aspirasyonu Olarak Prezante Olan 4 Yaşında Erkek \\ Çocukta Plastik Bronşit: Nadir Bir Durum
}

\author{
Saniye GIRIT ๑, Ebru SENOL ๑, Emel EROGLU ๑, Dilek ECE ๑, Tamer BAYSAL ๑
}

Ethics Committee Aproval: Not Applicable.

Confillict of Interest: The authors declare that they have no conflict of interest. Funding: None.

Informed Concent: Was taken.
Cite as: Girit S, Senol E, Eroglu E, Ece D, Baysal T. Plastic Bronchitis in a 4 YearOld Boy Presenting as Foreign Body Aspiration: A Rare Entity. Medeniyet Med J. 2019;34:213-7.

\begin{abstract}
Plastic bronchitis is a rare disease of pediatric age resulting from the fibrinous mucus plugs obstructing the airway. Plastic bronchitis can be secondary to many pulmonary and systemic diseases; but also it can be idiopathic. It is an important entity because it can present with acute respiratory system failure symptoms like non-productive cough, dyspnea and wheezing mimicking foreign body aspiration. Here, we present a 4-year-old boy diagnosed as plastic bronchitis by bronchoscopy. A 4-year-old boy was brought with cough and difficulty in breathing. He had wheezing and dyspnea in pyhsical examination and blood oxygen saturation was $92 \%$ without any other clinical and laboratory signs of infection. Chest $X$-ray and computerized tomography showed characteristics of foreign body aspiration. He was diagnosed as plastic bronchitis by flexible bronchoscopy and had full recovery after extraction of the plugs by aspiration in a bronchoscopy session. Plastic bronchitis is a rare entity of pediatric age. Patients who have respiratory failure resistant to conventional medical therapy; especially if they have radiologic signs of atelectasia or intraluminal blockage, should be evaluated with bronchoscopy.
\end{abstract}

Keywords: Child, plastic bronchitis, respiratory aspiration

öz

Plastik bronşit; hava yolunu tıkayan fibrinöz mukus plakları sonucunda oluşan, çocukluk çağında nadir görülen bir hastalıktır. Birçok pulmoner ve sistemik hastalığa sekonder olabileceği gibi, idiyopatik de olabilir. Hasta, balgamsız öksürük, dispne ve hışıltı ile yabancı cisim aspirasyonunu taklit edecek şekilde akut solunum yetmezliği bulguları ile başvurabileceği için önemli bir hastalıktır. Bu çalışmada, bronkoskopi ile plastik bronşit tanısı alan dört yaşındaki hastamızı sunuyoruz. Dört yaşında erkek hasta öksürük ve nefes almakta güçlük yakınmasıyla getirildi. Fizik muayenede ronküsler ve dispne mevcuttu, oksijen saturasyonu \%92 idi. Klinik ve laboratuvar olarak başka herhangi bir enfeksiyon bulgusu yoktu. Göğüs grafisinde ve bilgisayarlı tomografide yabancı cisim aspirasyonuna ait özellikler görüldü ve hastaya bu ön tanı ile bronkoskopi yapıldı. Bronkoskopide mukus plakların görülmesi ile plastik bronşit tanısı alan hastada plakların aspirasyonu sonrasında tam iyileşme izlendi. Plastik bronşit çocukluk çağında nadir görülen bir durumdur. Medikal tedaviye dirençli solunum yetmezliği bulguları olan hastalar; özellikle radyolojik olarak atalektazi veya intraluminal tıkanıklık bulguları da varsa yabancı cisim aspirasyonu yanında plastik bronşit de akılda tutularak bronkoskopi ile değerlendirilmelidir.

Anahtar kelimeler: Çocuk, plastik bronşit, solunum yolu aspirasyonu
Received: 09.11 .2018

Accepted: 17.12 .2018

Online First: 10.06 .2019

Corresponding Author: S. Girit

ORCID: 0000-0001-7556-6568 Medeniyet University Medical School Goztepe Educational and Research Hospital, Division of Pediatric Pulmonology, Department of Pediatrics, Istanbul - Turkey

saniyegirit@gmail.com

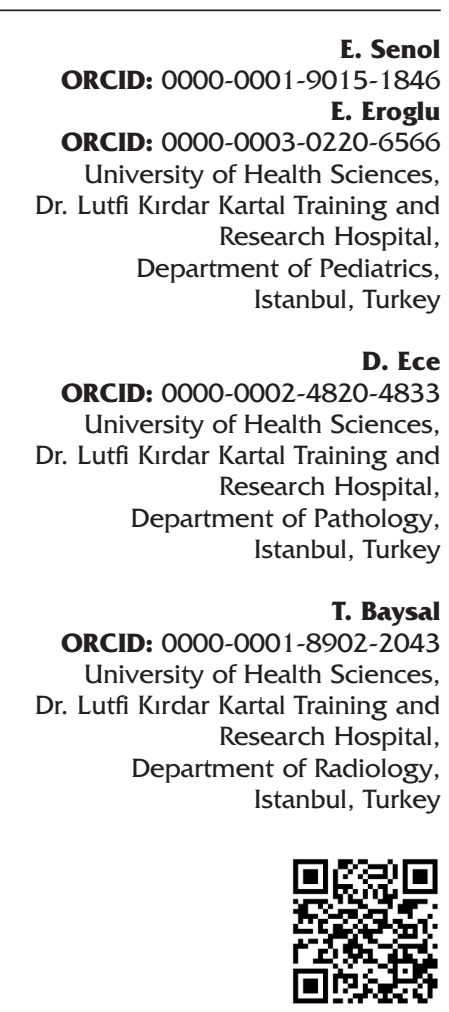




\section{INTRODUCTION}

Fibrinous bronchitis, plastic bronchitis or pseudomembranous bronchitis is a rare disorder which is characterized by formation of fibrinous mucus plugs that take the shape of the bronchial tree thereby blocking the airway ${ }^{1}$. Basicly, it is a lymphatic drainage defect with resultant respiratory failure. It is most commonly seen in patients with a history of Fontan operation or particular cardiac diseases accompanied by lymphatic anomalies. Plastic bronchitis can also be related to some respiratory diseases such as asthma, allergic bronchopulmonary aspergillosis, cystic fibrosis, bronchiectasis; as well as some systemic diseases such as sickle cell anemia or congenital cardiac disorders ${ }^{2,3}$. Plastic bronchitis can present with acute respiratory system failure symptoms like non-productive cough, dyspnea and wheezing mimicking foreign body aspiration ${ }^{4}$.

We report a 4-year-old male patient presenting with a cough. Atalectasia in the right upper pulmonary lobe was detected underwent bronchoscopy with the prediagnosis of foreign body aspiration.However the final diagnosis was plastic bronchitis and he was treated with flexible bronchoscopy.

\section{CASE REPORT}

A 4-year 5-month-old boy applied to our clinic with cough persisting for the last week, and accompanied by difficulty in breathing for the last few days. He didn't have a history of fever or foreign body aspiration. There was no respiratory history other than admission to hospital for pneumonia when he was 6 months old. His growth parameters were appropriate for his age, with body temperature of $36,8^{\circ} \mathrm{C}$, respiratory rate of 36/min and $\mathrm{SpO}_{2}$ : \%92 without oxygen support. In physical examination; he was dyspneic with intercostal retractions in right hemithorax and had significant wheezing at the same side; whereas other systems were normal. Laboratory evaluation revealed normal leukocyte, eosinophil, hemoglobin, erythrocyte sedimentation and C-reactive protein (CRP) values. In posteroanterior chest $X$-ray there was an opacity in the right mid-upper zones starting from the right hilus and extending to peripheral areas without air bronchograms (Figure 1a). Computerized tomography (CT) revealed parenchymal consolidation in the right upper paramediastinal areas, and peribronchovascular areas of infiltration with increased density in apicoposterior segments, and in mediobasal peribronchovascular areas of the right lower lobe. Thorax CT also revealed plugs in the right upper

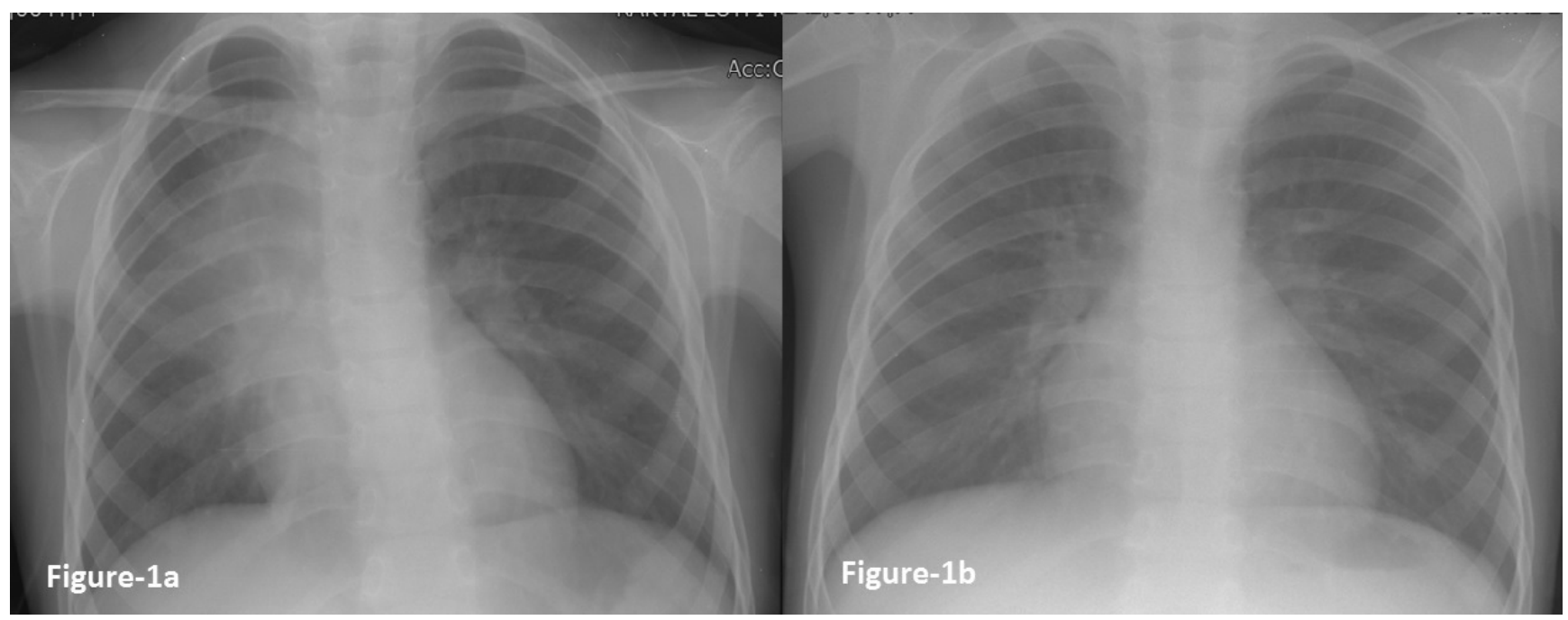

Figure 1a-b. X-ray; consolidated area by the right hilus (a); after extraction of the mucus plugs by bronchoscopy (b). 
lobe bronchus causing interruption in air column (Figure 2).

Patient was started on antibiotic regimen with ampicillin-sulbactam. On the fifth day of the treatment the second chest $\mathrm{X}$-ray revealed the presence of a bit smaller consolidated area. Patient underwent flexible bronchoscopy with the prediagnosis of foreign body aspiration. In bronchoscopy; the white mucoid fibrinoid plugs obstructing right upper lobe, middle lobe and lower lobe superior segment bronchi were discovered (Figure 3a). The plugs were extracted by aspiration using a flexible bronchoscopy (Figure 3b). Histopathology of the plugs was reported as necrotic-necrobiotic fibrinous mucinous material which included cells thought to be originated from bronchial epithelia and inflammatory cells without Charcot-Leyden crystals (Figure 4). Bronchoalveolar lavage fluid was normocellular and both pyogenic and tuberculosis cultures were sterile. Patient was diagnosed as plastic bronchitis. Follow-up chest X-ray 2 days after bronchoscopy revealed significant remission of the consolidated area (Figure 1b).

For evaluation of secondary causes of plastic bronchitis; patient history was re-examined throughly, there was no history leading to asthma or cardiac diseases. Skin prick tests were negative and patient couldn't accomplish spirometry. Echocardiographic and cardiac evaluation was also unremarkable. No underlying conditions were detected.

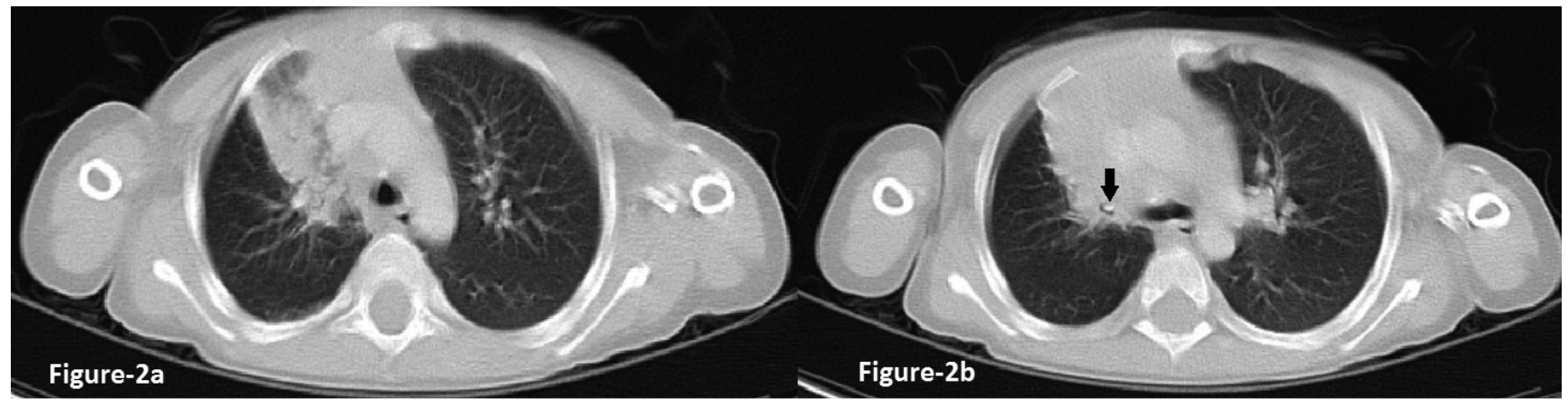

Figure 2a-b. Chest CT; consolidated areas in right upper paramediastinal areas and apicoposterior segments (a); obstructed right upper lobe bronchus (arrow,b).

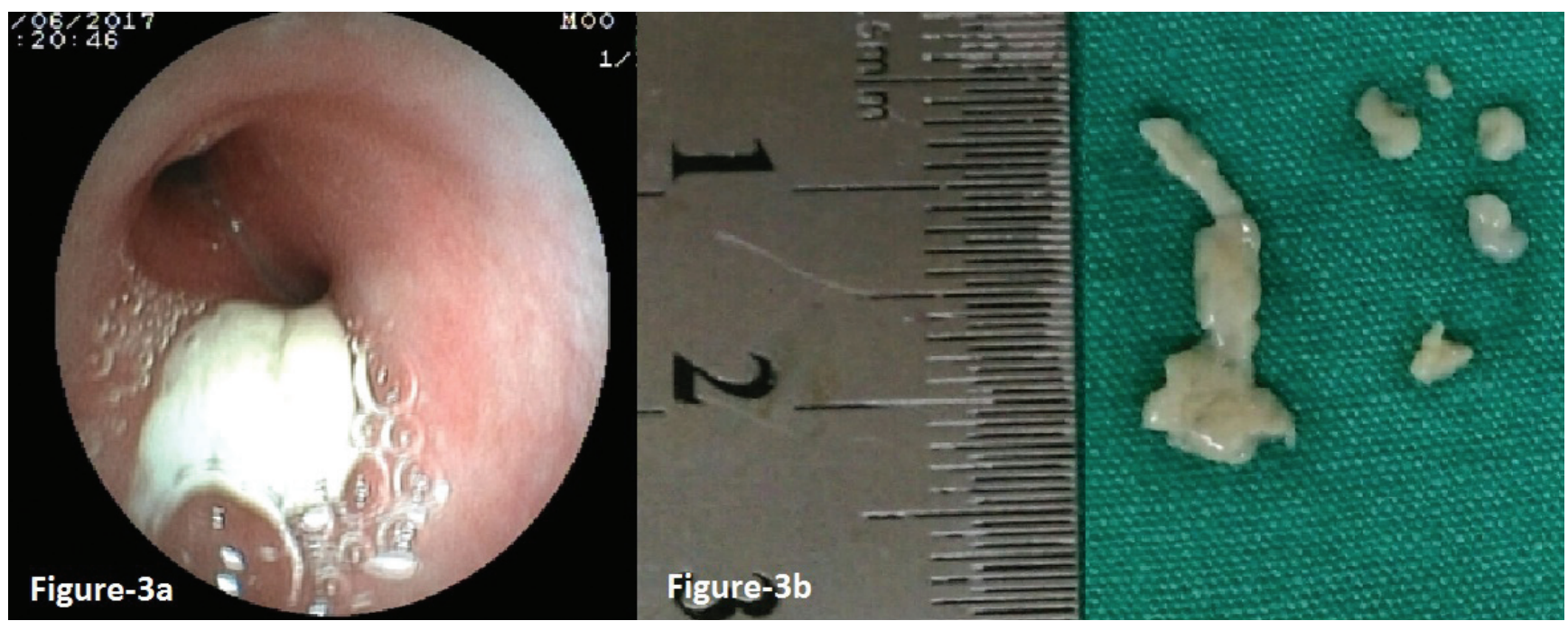

Figure 3a-b. Bronchoscopic image of the mucus plugs (a); macroscopic image of the multiple mucus plugs in the shape of bronchial tree $(\mathbf{b})$. 


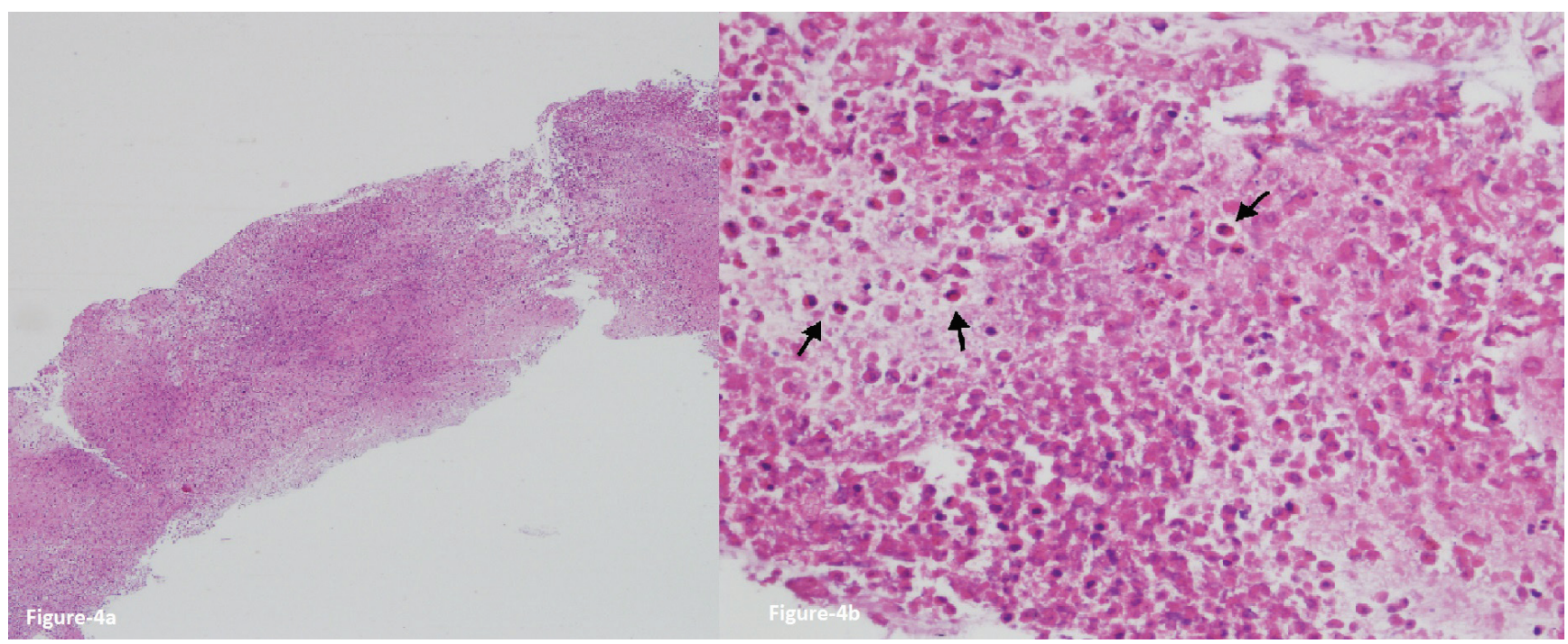

Figure 4a-b. Fibrinous material containing degenerated cells, HE, x40 (a); degenerated cells in which few visible eosinophils are indicated by the arrows, HE, x400 (b).

Our patient is now followed for almost 18 months and he hasn't developed any respiratory symptoms or signs and didn't need repetitive bronchoscopic examinations.

\section{DISCUSSION}

Plastic bronchitis-also called fibrinous bronchitis or pseudomembranous bronchitis-is a very rare disease. The plugs occupying and taking the three-dimensional shape of the bronchial tree can be seen via bronchoscopy, which can also be expectorated spontaneously 5 . Expectorated plugs can be mistaken as aspirated food by parents6.

Plastic bronchitis can be the result of pulmonary disorders such as asthma, allergic bronchopulmonary aspergillosis, cystic fibrosis, bronchiectasis, recurrent pulmonary infections, acute chest syndrome associated with sickle cell anemia; or non-pulmonary disorders such as congenital cardiac diseases, heart failure, pericardial effusion and Fontan operation ${ }^{2,3}$. Our patient didn't have any sign or symptoms of these etiologic factors in his history, physical examination or laboratory tests; so plastic bronchitis in our case was diagnosed as idiopathic.
Pathogenic mechanisms leading to plastic bronchitis is still not fully explained; but two main theories were proposed ${ }^{6}$. First of these is deterioration of bronchial epithelial function secondary to inflammation or infections (caused by cystic fibrosis, astma, sickle cell anemia etc); while second theory is disrupted pulmonary lymphatic drainage.

First symptoms of plastic bronchitis can mimic foreign body aspiration or obstructive pulmonary diseases non-responsive to treatment ${ }^{7}$. Depending on the degree of airway obstruction; symptoms and signs such as cough, chest pain, fever, dyspnea, wheezing and hypoxia can be seen. In the differential diagnosis; other causes of bronchitis and foreign body aspiration must be kept in mind. Our patient had a history of cough and dyspnea for only a few days which started abruptly. There was no story of foreign body aspiration but with the symptoms and radiological appearance; flexible bronchoscopy was performed with the initial diagnosis of foreign body aspiration.

Plugs formed in plastic bronchitis was histologically classified in two groups by Seear et al. ${ }^{4}$. In the first group, namely inflammatory group, plugs have less mucus and more abundant cell infiltra- 
tes rich of fibrin and eosinophils. Second group of plugs, namely acellular group, have plenty of mucus, less fibrin and rarely mononuclear cells ${ }^{2,4}$. Our patient's histological evaluation had the characteristics of the inflammatory group plugs.

Plastic bronchitis is diagnosed by histological examination of mucus plugs which are extracted by bronchoscopy and/or expectorated by the patient. In radiological investigations; atelectasia on the effected side, hyperinflation of the contralateral lung, mediastinal shift to the atelectatic side, pneumomediastinum and emphysema can be seen ${ }^{8}$. Our patient had paramediastinal atelectasia radiologically and was diagnosed by bronchoscopy. His first radiologic evaluation was made by $x$-ray; and since there was atelectasis on the right middle and upper zones; thorax CT was requested to evaluate other possible causes of atalectasis.

There is no specific treatment modality for plastic bronchitis. Basic approach is to remove the mucus plugs and to find and treat the underlying reason thus preventing formation of new plugs. Removal of the plugs with rigid bronchoscopy is still suggested as the main treatment modality in a studies with large patient series ${ }^{9,10}$. Bronchochodilators, $\mathrm{N}$-acetylcystein, dornase alpha, inhaler tissue plasminogen activators and respiratory physical therapy can be used in addition ${ }^{11,12}$. Removal of the casts with serial flexible bronchoscopies performed after local aerosolized heparin application was also reported ${ }^{13}$. We had the opportunity to aspirate and remove the plugs with flexible bronchoscopy and the intervention was accomplished successfully without any complications.

On the follow-ups, our patient didn't have recurrence of plastic bronchitis and didn't need recurrent bronchoscopic examinations.

Mortality is determined by the underlying causes in plastic bronchitis. Mortality is between $28 \%$ to $60 \%$ in plastic bronchitis secondary to cardiac diseases; whereas mortality rate is $6 \%-50 \%$ in cases secondary to pulmonary infections ${ }^{9,11}$.

As a conclusion; plastic bronchitis is a rare entity in pediatric age group which can present with symptoms mimicking foreign body aspiration. Patients who have respiratory failure resistant to conventional medical therapy; especially if they have radiologic signs of atelectasia or intraluminal blockage, should be undergo bronchoscopic examinations.

\section{REFERENCES}

1. Berlucchi $M$, Pelucchi F, Timpano S, Zorzi A, Padoan R. A conservative treatment for plastic bronchitis in pediatric age. Am J Otolaringol. 2014;35:204-2. [CrossRef]

2. Brogan TV, Finn LS, Pyskaty Jr DJ, et al. Plastic bronchitis in children: a case series and review of the medical literature. Pediatr Pulmonol. 2002;34:482-5. [CrossRef]

3. Kao NL, Richmond GW. Cough productive of casts. Ann Allergy Asthma Immunol. 1996;76:231-2. [CrossRef]

4. Seear M, Hui H, Magee F, Bohn D, Cutz E. Bronchial casts in children: a proposed classification based on nine cases and a review of the literature. Am J Respir Crit Care Med. 1997;155:364-6. [CrossRef]

5. Bayram M, Döngel İ, Akkoyunlu ME, Levent K. A rare cause of chronic cough: Plastic Bronchitis. Respir Case Rep. 2014;3:101-2. [CrossRef]

6. Özer E, Pampal H, Bulut Ş, Numanoglu N. Bir plastik (fibrinöz) bronşit olgusu. Ankara Üniversitesi Tıp Fakültesi Mecmuası. 2009;62:131-3. Available from: http://dergiler.ankara.edu.tr/dergiler/36/1329/15368.pdf [CrossRef]

7. Cairns-Bazarian AM, Conway EE Jr, Yankelowitz S. Plastic bronchitis an unusual cause of respiratory distress in children. Pediatr Emerg Care. 1992;8:335-2. Available from: https://hkspra.org/product_image_pub/255_688056. pdf [CrossRef]

8. Noizet $\mathrm{O}$, Leclerc F, Leteurtre S, et al. Plastic bronchitis mimicking foreign body aspiration that needs a specific diagnostic procedure. Intensive Care Med. 2003;29:329-3. [CrossRef]

9. Madsen P, Shah SA, Rubin BK. Plastic bronchitis: new insights and a classification scheme. Paediatr Respir Rev. 2005;6:292-8. [CrossRef]

10. Soyer T, Yalcin S, Emiralioglu $N$ et al. Use of serial rigid bronchoscopy in the treatment of plastic bronchitis in children. J Pediatr Surg. 2016;51:1640-3. [CrossRef]

11. Eberlein MH, Drummond MB, Haponik EF. Plastic bronchitis: a management challenge. Am J Med Sci. 2008;335:163-6. [CrossRef]

12. Gibb E, Blount R, Lewis $\mathrm{N}$ et al. Management of plastic bronchitis with topical tissue-type plasminogen activator. Pediatrics. 2012;130:e446-e50. [CrossRef]

13. Walker PA, Shah SK, Letourneau PA et al. Treatment of plastic bronchitis using serial flexible bronchoscopy and aerosolized heparin therapy. Eur J Pediatr Surg 2013;23:157-60. [CrossRef] 